\title{
WestVirginiaUniversity
}

THE RESEARCH REPOSITORY @ WVU

Graduate Theses, Dissertations, and Problem Reports

2011

\section{The Politics of Self-provisioning in North-central West Virginia}

Autumn Long

West Virginia University

Follow this and additional works at: https://researchrepository.wvu.edu/etd

\section{Recommended Citation}

Long, Autumn, "The Politics of Self-provisioning in North-central West Virginia" (2011). Graduate Theses, Dissertations, and Problem Reports. 688.

https://researchrepository.wvu.edu/etd/688

This Thesis is protected by copyright and/or related rights. It has been brought to you by the The Research Repository @ WVU with permission from the rights-holder(s). You are free to use this Thesis in any way that is permitted by the copyright and related rights legislation that applies to your use. For other uses you must obtain permission from the rights-holder(s) directly, unless additional rights are indicated by a Creative Commons license in the record and/ or on the work itself. This Thesis has been accepted for inclusion in WVU Graduate Theses, Dissertations, and Problem Reports collection by an authorized administrator of The Research Repository @ WVU. For more information, please contact researchrepository@mail.wvu.edu. 


\title{
The Politics of Self-provisioning in North-central West Virginia
}

\author{
Autumn Long \\ Thesis submitted to the \\ Eberly College of Arts and Sciences \\ at West Virginia University \\ in partial fulfillment of the requirements \\ for the degree of
}

Master of Arts

in

Geography

Bradley Wilson, Ph.D., Chair

Brent McCusker, Ph.D.

Ann Oberhauser, Ph.D.

Department of Geology \& Geography

Morgantown, West Virginia

2011

Keywords: Self-provisioning; Food provisioning; Food politics; West Virginia; Northcentral West Virginia; Labor value; Diverse economies

(C) 2011 Autumn Long 


\title{
ABSTRACT \\ The Politics of Self-provisioning in North-central West Virginia
}

\begin{abstract}
Autumn Long
Provisioning one's own food appears to be the next step in the politicization of food production and consumption choices. In contrast to more convenient forms of "ethical consumption" such as buying organic or local, household-level food production requires a great deal of labor-time, knowledge, and social support. But does food self-provisioning elicit or engender a particular political consciousness? Based on six months of fieldwork conducted during the spring and summer of 2010, this research employs qualitative methodologies, including surveys, semistructured interviews, and ethnography, to examine the political, economic, and cultural dynamics of household-level food provisioning amongst a sample of food self-provisioners in north-central West Virginia. I argue here that the work involved in food provisioning activities such as gardening, raising livestock, hunting, fishing, and foraging can be conceptualized as noncapitalist labor, a potential site of resistance to capitalist agro-industrial hegemony. Yet, as this research demonstrates, non-capitalist labor does not necessarily predicate an intentionally anticapitalist subject with counter-hegemonic political goals or motivations. In fact, analysis of the data collected through this research reveals the existence of four distinct subgroups of selfprovisioners within the overall sample whose self-provisioning activities are informed by a range of different political, economic, and cultural motivations. Despite their diverse motives and understandings, however, the inherently non-capitalist labor of self-provisioning provides a unifying theme that connects self-provisioners across political, cultural, and economic difference.
\end{abstract}




\section{Acknowledgements}

I would like to thank my advisor and thesis committee chair, Dr. Bradley Wilson, for his unwavering support, invaluable guidance, and boundless enthusiasm throughout the entire course of this project. I also would like to thank the other members of my thesis committee, Dr. Brent McCusker and Dr. Ann Oberhauser, for their assistance, advice, and encouragement. I extend sincere thanks to the faculty, staff, and graduate students at West Virginia University’s Department of Geology and Geography for making my M.A. experience such a positive one.

I am deeply indebted to my informants, whose participation made this work possible and whose enthusiasm made it a joy. I feel blessed to have worked with such a vibrant and generous group of research subjects.

To my dear family, thank you for a lifetime of love and support. I am who I am today because of you. Last but certainly not least, thank you to my best friend and husband, Dan, whose love sustains me every day. 


\section{Table of Contents}

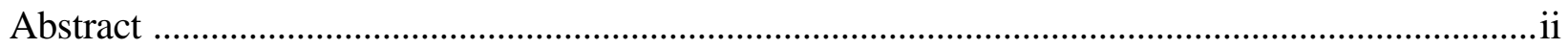

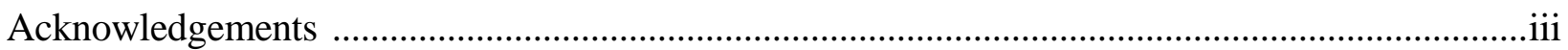

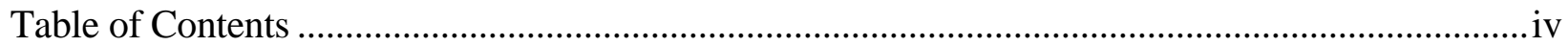

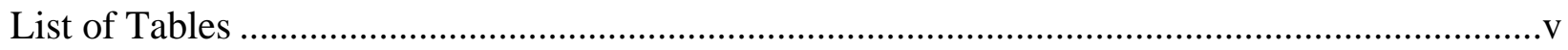

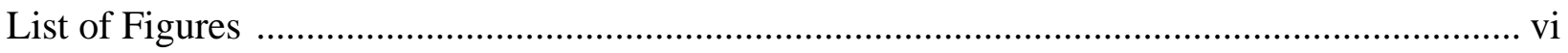

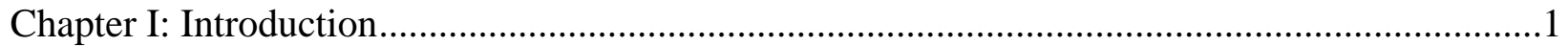

Chapter II: Background \& Literature Review ............................................................................ 6

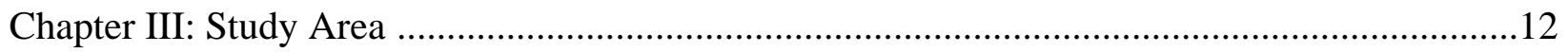

Chapter IV: Methodology .................................................................................................15

Methodological Framework.....................................................................................15

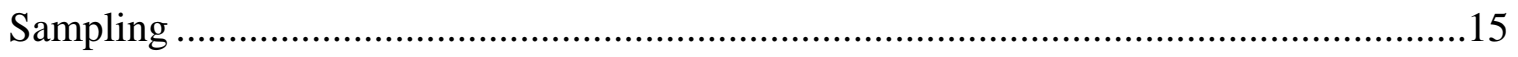

Surveys and Interviews ............................................................................................16

Ethnography and Positionality ....................................................................................18

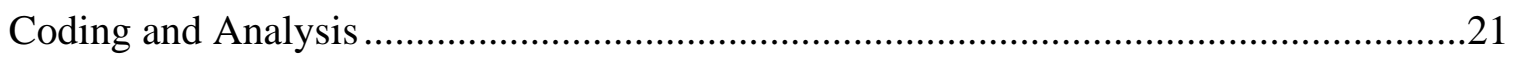

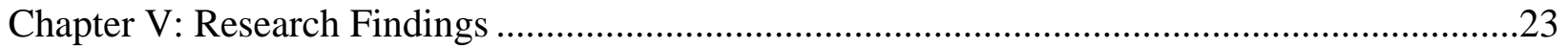

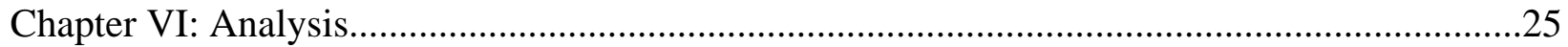

Group 1: “The Back-to-the-Landers” ...........................................................................27

Group 2: “The Hobbyists” ..............................................................................................32

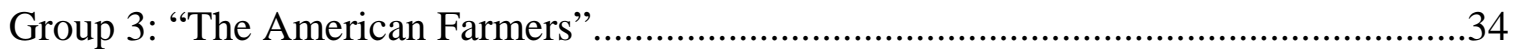

Group 4: "The Movement” ............................................................................................39

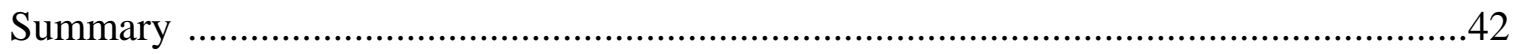

Chapter VII: Discussion and Conclusion ..................................................................................

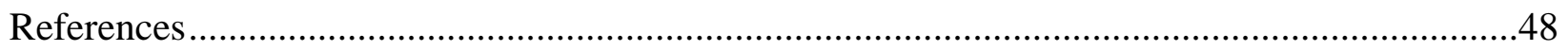

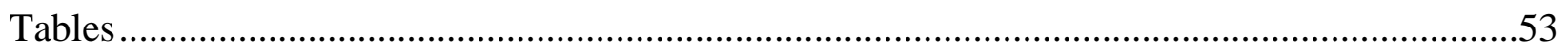

Appendix A: Household Economic Survey ........................................................................60

Appendix B: Interview Guide .............................................................................................63

Appendix B: Institutional Requirements ..........................................................................64 


\section{List of Tables}

Table 1: Vegetables grown in participant households ...............................................................53

Table 2: Fruits and nuts grown in participant households ......................................................... 54

Table 3: Field crops grown in participant households ..........................................................55

Table 4: Herbs grown in participant households ..............................................................56

Table 5: Livestock raised in participant households .......................................................57

Table 6: Hunting and fishing in participant households .......................................................58

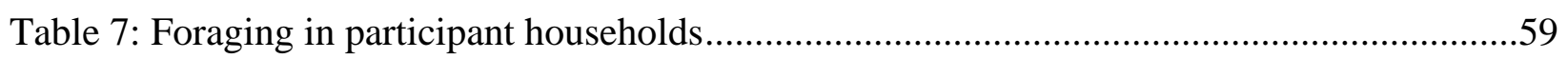




\section{List of Figures}

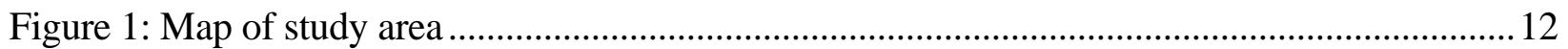

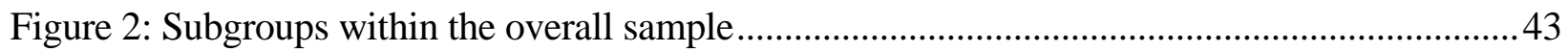




\section{Chapter I: Introduction}

On a sunny September morning in 2010, I eased my car over a rickety metal bridge at the mouth of a narrow mountain stream and pulled into the circular driveway of a sturdy two-story farmhouse. With a deep wrap-around porch and fresh coat of vivid green paint, the old house had a cheerful, welcoming air. Grape vines grew on trellises in the center of the driveway roundabout, and a clearly contented cat draped herself over a shady porch railing.

In a low-lying field between house and creek, half a dozen figures bent low toward the dark, rich soil of the flood plain, stepping slowly along rows of freshly oturned soil, picking up potatoes and placing them in burlap sacks, plastic buckets, and cardboard boxes. I stood silently for a moment, observing them at their work, mildly surprised at their youth and noting the dreadlocks, tattoos, and piercings that adorned some members of the group. My eyes came to rest on the figure of a man driving a small blue tractor with a plow attached to a three-point hitch. 'Now, who might this be?' I thought to myself. The man was much older than the field workers, with salt-and-pepper hair and an air of quiet authority. I was intrigued to find out more about him and his role in the group.

I had come to this snug, stream-carved box hollow in north-central West Virginia to interview the group’s head gardener about his household’s food provisioning activities. It seemed I had arrived just in time to experience some of that provisioning first-hand, and so I headed out to the field to offer my assistance in completing the year's potato harvest. After exchanging quick introductions, my offer of help was gratefully accepted, and soon I, too, was bending over the freshly turned earth, plunging my hands up to the wrists in feathery-soft soil to uncover the white- and red-skinned tubers, dropping them into a bucket and taking a step up the row. Bend, reach, step. Bend, reach, step. The rhythm of the work was pleasant, and the morning 
sun warmed my back as I moved up the row. Beads of sweat were just beginning to form along my lip and hairline as I hauled two full buckets back down the row, my eyes glued to the ground, searching for potatoes I might have overlooked.

I heaved the buckets into a truck bed piled high with lumpy bags and dirt-smeared boxes filled with potatoes. The man on the tractor finished turning over the last row, raised the plow out of the ground, and parked the machine at the edge of the field. The workers took deep swigs from water bottles and eyed the truck bed thoughtfully, making guesses at how many bushels of potatoes they had harvested that morning. The older man joined the group, grinning and cracking jokes in the slightly twangy local accent, his ice-blue eyes flashing merrily beneath the brim of a floppy straw hat. “D’ye think ye'd help me get the rest'a mine dug out now?” he inquired of the young people lounging on the truck's tailgate. They agreed without hesitation: After all, he'd just spent the morning plowing their potato patch; it would be only fair to return the favor.

I introduced myself to the man, whom by then I had concluded to be a neighbor. I briefly explained why I was there and wasted no time in asking him to participate in my research. He agreed with a chuckle and told me to stop by his house, “the next one up the holler," after I had finished my other business. But now it was time to get back to work: Another potato patch awaited us, though this one smaller than the field we had just harvested (after all, it would go to feed only one person rather than a sprawling household of nine adult members). We walked a quarter-mile up the road to the next farmstead and began a fresh round of harvesting. The old man led the way on the tractor as the scent of freshly turned earth filled our nostrils. We followed behind, scurrying up and down the rows, stuffing bags and boxes with the firm, round tubers that would in turn fill the old man's belly during the coming winter. Pommes de terre. Apples of the earth, indeed. 
As it turned out, the man I met that day was much more than a neighbor to the young people I had come to interview. It was his land on which they lived and farmed, the land where he had been born and raised, and now he leased it to his neighbors, free of charge. The house, gardens, fields, and forests: All were theirs to use and cultivate. Not least of these generous gifts was the old fellow's knowledge, a lifetime of skills, experience, and wisdom that he clearly delighted in sharing with the greenhorns.

My experiences that day exemplified certain aspects of the work upon which I had embarked. I wanted to understand more deeply the complex and challenging work involved in provisioning one's own food, and the no less complex and challenging people who undertake such work. That day's potato harvest represented a culmination of the shared labor of family, friends, and neighbors — people from very different backgrounds and with possibly different motivations for their work, who nonetheless labor together to provision food for themselves and their families. This is work that can be physically arduous and mentally taxing; it demands strength, perseverance, organization, flexibility, and resilience from those who undertake it. Why had these people gone to all the trouble of preparing, planting, tending, and harvesting a field of potatoes, when they were perfectly capable of simply driving to the supermarket and buying a bag of Idaho spuds? Surely, forces other than pure economic necessity inspired them to labor in such a way.

Through this research, I sought to explore the political, economic, and cultural motives and strategies that drive some people in the United States today to provision their own food. While food self-provisioners share a common, and notable, form of labor, that work may articulate with very different understandings of food politics and food systems. I did not expect this research to generate a unified picture of the self-provisioning subject. Rather, I sought to 
better grasp the range of political perceptions and material circumstances that together form a variegated politics of self-provisioning. The diversity I witnessed that day in a group of people working together in a potato patch reinforced this hypothesis and demonstrated how difference can be maintained and respected even while reaching common goals.

The remainder of this paper details the research I have conducted amongst a sample of food self-provisioners in north-central West Virginia. This research examines the political motivations that prompt contemporary West Virginians to undertake self-provisioning activities, as well as the material circumstances in which they perform those activities. I begin with a literature review that places self-provisioning in the contemporary United States within a larger sociopolitical context of "ethical consumption." This section also examines the production and consumption strategies involved in self-provisioning through a theoretical lens of diverse economies. Next, I lay out my research questions and briefly introduce readers to the study area in which the research was conducted. The following section explains the methodologies I have employed in conducting this research and details research findings within the overall sample. Next, I explain my analytical methods and share the results of that analysis, which identifies and describes four subgroups within the overall sample of self-provisioners: “The Back-to-theLanders,” “The Hobbyists,” “The American Farmers,” and “The Movement.” Members of each of these subgroups generally engage in a common set of food provisioning and consumption strategies; operate within the bounds of broadly similar material circumstances; and share particular political views relating to mainstream and alternative food systems which set them apart from other groups. I conclude by discussing how these findings impact our understandings of self-provisioning and its relations to larger food systems. I also suggest some implications of 
this work for our conceptualization of ethical consumption and the role of self-provisioning in diverse economic formations. 


\section{Chapter II: Background \& Literature Review}

In these early years of the $21^{\text {st }}$ century, only $6 \%$ of the rural U.S. workforce is employed in farming, and most rural residents commute to jobs outside the home (Miller \& Johnson 2009: 12). In fact, off-farm earnings from wages, salaries, and non-agricultural entrepreneurial activities account for nearly 90\% of all U.S. farm household income (Miller \& Johnson 2009: 18). At the same time, a few major corporations are increasingly consolidating their control over the U.S. food system. For the small percentage of rural residents who remain employed in farming, the proportion of U.S. agriculture carried out under contract to large agribusiness corporations has increased from $10 \%$ to $35 \%$ in the past two decades (Tulip \& Micheals 2004: 29). Four corporations control more than $80 \%$ of the nation's beef packing; and three firms handle more than half of its grain milling (Hubbard 2009: 10). Perhaps even more striking is the fact that only four companies control half of the world's proprietary seed market (i.e., branded varieties subject to intellectual property protections) (Hubbard 2009: 6). Genetically engineered seeds developed and patented by the Monsanto Corporation account for more than $80 \%$ of U.S. corn acres and more than $90 \%$ of U.S. soybean acres (Hubbard 2009: 10). On the consumption side of the spectrum, by 2001 the five largest U.S. supermarket chains had gained control over $41 \%$ of all food sold through the nation's supermarkets and $31 \%$ of all food sold through all kinds of retail stores (Smith 2001). The three largest of these supermarket chains control nearly a quarter of all food sales in the United States (Smith 2001).

In light of these statistics, it is easy to understand why American agriculture is often presented as dead or dying (e.g., Hightower 1975; Browne et al. 1992; Blank 1998). Yet, contemporaneously with these ongoing trends of consolidation and corporatization of the food system, in the past decade we have witnessed an explosion of public interest and popular writing 
pertaining to food and agriculture (e.g., Shiva 2000; Schlosser 2001; Halweil 2002; Petrini 2003; Pollan 2006; Kingsolver 2007; Patel 2007; Nabhan 2008). These recent works critique the dominant, industrial, globalized food system and propose a variety of agricultural alternatives to that sytem, from well-established concepts such as organic farming and fair trade to more recently coined terms such as locavorism, foodsheds, slow food, and community-supported agriculture. In the public imagination, at least, food and agriculture is alive and well — but in alternative forms.

These alternative agro-food formations represent more than just public imaginaries and book sales. Changing consumer interests and consumption practices in the past decade have led to significant increases in market shares for alternative food production and distribution systems. Sales of organic foods have grown 20\% annually in the past five years (OTA 2010). From 1997 to 2007 direct-to-consumer food sales grew by over 100\% (Diamond \& DeSoto 2009). In the past 15 years, the number of operating farmer's markets in the United States has increased from under 2,000 to over 5,000, with a 13\% increase in the single year of 2008-2009 (USDA 2009). In 1990, there were only about 60 community-supported agriculture programs (aka CSAs) operating in the United States. By 2007, more than 12,500 U.S. farms had developed CSA programs (USDA 2007).

The search for alternatives to the dominant food system has centered largely on consumption choices, with the concept of "ethical consumption" driving changes in production conditions to meet shifting consumer interests (Busch 2000; Barham 2002). Ethical food consumption encompasses a wide-ranging set of objections to mainstream industrial agriculture, from environmental impacts (e.g., the "organic” paradigm and its overarching discourse on sustainability) to issues of social justice (e.g., the "fair trade" paradigm and associated concerns 
for working conditions, living wages, secure pricing, etc.). But one characteristic unites these myriad concerns under the mantle of ethical consumption: assessment of a product's value based on criteria that extend beyond the economic sphere (Barham 2002). By emphasizing other values such as locality, process, and quality, supporters of contemporary agro-food movements are essentially attempting to politicize the market economy by suggesting that shared social norms, standards, and expectations are and should be taken into account in economic decision-making (Barham 2002). Such movements often are presented as counterhegemonic to the mainstream food system — as progressive, even radical forms of resistance to that system.

Does ethical consumption represent a real challenge to the hegemonic food culture? By making ethical consumption choices, the consumer is encouraged to view herself as an agent of change whose lifestyle decisions manifest resistance to the mainstream food culture and present a real challenge to the global industrial agro-food system. Yet, central to the paradigm of ethical consumption is the role of the consumer as divorced from that of the producer. In a capitalist economic system, the products of a worker's labor do not legally belong to the worker who produces them (i.e., estranged labor), thereby forcing workers to become consumers in order to purchase the necessary goods that they or others have produced (Bocock 1993: 37). As Bocock points out, consumption becomes part of the process of alienation precisely because it is cut off from the process of production (1993: 44).

While ignoring their productive roles (as workers from whom surplus value is extracted) in perpetuating the ongoing violence of the capitalist system, ethical consumers seek to engage in political action simply by shopping “well” or “responsibly” (Carlsson \& Manning 2010: 933). Yet, it is through consumerism that capitalism succeeds in doubly extracting the value of labor. This is accomplished by recasting the laborer as a consumer whose consumption activities 
effectively recapture whatever part of her labor's value she was permitted to retain — as well as her non-labor time — for capitalist accumulation. Even an ethical consumer's labor time and practices remain motivated by the needs and desires of consumption, thereby maintaining the material basis for the ongoing accumulation of capital through the extraction of surplus labor value (Marx 1973: e.g., 325, 451, 455). This is made possible by the very acts of consumption through which the ethical consumer seeks to express her opposition to the practices and consequences of the capitalist economic system.

The story does not stop here, however, so let's not become too discouraged by the shortcomings of supposedly radical agro-food movements that some researchers (Barham 2002; Guthman 2004; Slocum 2006) argue remain subsumed within the mainstream economy. A growing body of work by poststructuralist and feminist theorists employs the concept of diverse economies to challenge the hegemony of global capitalism, investigate the possibilities of active spaces of economic opportunity, and promote non-capitalist economic forms (e.g., Nelson \& Smith 1999; Cameron \& Gibson-Graham 2003; Leyshon, Lee, \& Williams 2003; Barron 2005; Oberhauser 2005; Gibson-Graham 2006a, 2006b; Solnit 2010). Gibson-Graham asks us to imagine the economy as an iceberg, with the visible, and much smaller, portion consisting of what is typically acknowledged as economic activity (i.e., wage labor, market commodity exchange, capitalist enterprise). Yet, submerged below the waterline (and therefore obscured from sight) lurks the vast majority of activities through which we actually produce, exchange, and distribute values (Gibson-Graham 2006b: 68-70). This diverse "iceberg economy” includes a vast array of transactions, enterprises, and forms of labor, ranging from intrafamily household work and care-giving to independent self-provisioning activities (e.g., hunting, gathering, poaching, even theft), communal gift exchanges, and informal market transactions such as barter, 
cooperative exchange, local currency systems, and black-market activities (Gibson-Graham 2006b: 60-65). In this way, activities and projects that at first glance appear mundane, noneconomic, or apolitical can be reexamined with a more expansive vision of what constitutes economic activity and political action. My work investigates some such diverse economic activities that are taking place within a sample of food self-provisioners in north-central West Virginia.

Cultivating a garden, raising livestock, hunting wild game: These activities require the use of labor time in ways that are directly at odds with the accumulation of capital. Rather than spending a given amount of labor time working for wages, then using those wages to buy commodities, self-provisioners spend that time performing a different, noncapitalist kind of work. In contrast to the objectification of labor and concomitant commodification of labor's products essential to the capitalist economy, self-provisioning provides an opportunity for workers to retain the products of their labor. Moreover, a self-provisioner has the power to decide what forms those products will take.

Using the example of contemporary harvesters of non-timber forest resources (NTFRs), Barron (2005) points out that self-provisioners are "in control of the production and the appropriation of the surplus which [they are] creating” (73). This type of labor is not "taken over or made obsolete by the seemingly hegemonic capitalist system” (Barron 2005: 73). Rather, it remains precisely the kind of non-alienated, non-appropriated labor that Marx understood to be work - that is, labor which creates qualitative use-values rather than the quantitative exchange values created through wage labor in the capitalist system (Ollman 1971: 175, 294). Under capitalism, labor has no use value for the laborer; it is not productive for her (Marx 1973: 305307). A self-provisioner, on the other hand, experiences her labor as a productive force that 
creates use values, or, in Marx’s words, that “really free” labor (1973: 611) which retains control over its products and relations. In other words, self-provisioners “ “work' or 'labor' in a way in which the particular substance of their activity is meaningful” (Carlsson \& Manning 2010: 925, ital. orig.).

Should we take these signs to mean that self-provisioners are purposely attempting to construct a counterhegemonic lifestyle in relation to the hegemonic food system? Their work has certainly become associated with the purportedly counterhegemonic agendas of alternative agrofood movements. Or is it that the idea of self-provisioning has been co-opted, even commodified, in order to advance the goals and agendas of agro-food interests both within and outside the mainstream? How do self-provisioners view the hegemonic food system? How do they view contemporary agro-food movements that claim to challenge that system? Do they identify themselves and their food provisioning strategies as a form of ethical consumption? These are the questions I set out to answer through this research. 


\section{Chapter III: Study Area}

This research focuses on a geographical case study of food self-provisioners in the northcentral region of West Virginia. This region includes Monongalia, Marion, Taylor, Harrison, and Doddridge counties (see Figure 1, below). Due to the time constraints of my graduate program, I chose to focus on this region because I am familiar with it; I had convenient access to it; and I had previously established contact with some potential informants there. In addition to these pragmatic concerns, I recognized that this study area likely contained many potential informants for my research due to the region’s history of economic marginalization and rugged, mountainous terrain primarily suitable for small-scale and subsistence-level agriculture practiced in dispersed rural homesteads.

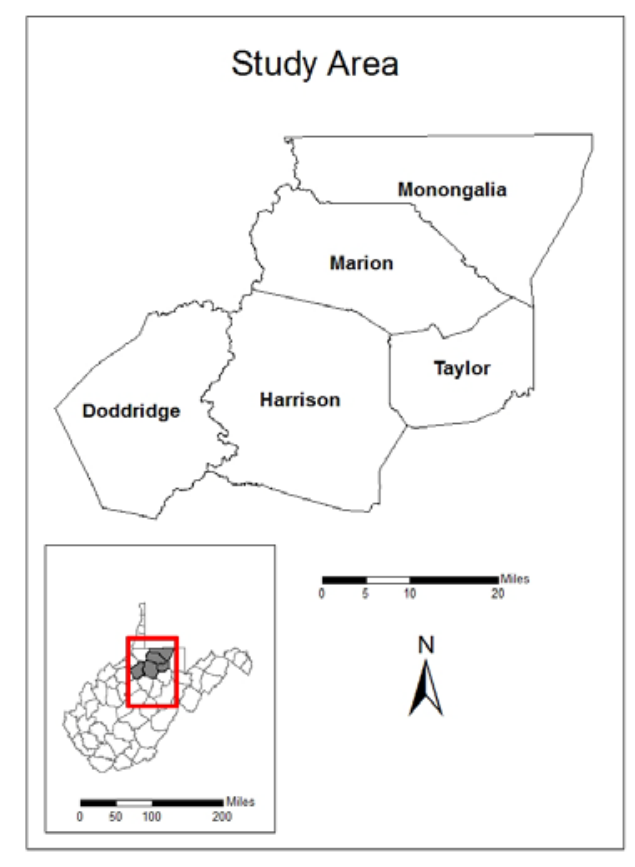

Figure 1. Map of study area.

In the early $19^{\text {th }}$ century, Scotch-Irish and German settlers began to carve out homesteads in what is now north-central West Virginia. Situated northwest beyond the Allegheny Front, the steep mountains and narrow valleys of present-day West Virginia were difficult to access and 
traverse, with little land area suitable for commercial agriculture (Salstrom 1995). Western Virginia’s agricultural economy centered on livestock as a supplement to subsistence agriculture, in contrast to the cash-crop monocultures that dominated eastern Virginia (Lewis 1998). Early residents developed an agrarian society with an informal economy based on barter and trade. Farming was their main occupation, but abundant wild game, fish, and plants were important food sources as well. Maize, or corn, was essential to life in Appalachia: Consumed by humans and livestock alike, it also can be fermented and distilled into homemade whiskey, aka moonshine. Rural settlers traded moonshine and farm-grown produce at general stores for staples such as salt, coffee, and nails; and sold them for cash needed to pay taxes (Shackelford \& Weinberg 1977).

In the mid-1800s, industrialists began to recognize Appalachia’s incredible richness in timber and mineral resources. Speculators purchased mineral rights from local landowners at extremely low prices, often less than a dollar an acre (Shackelford \& Weinberg 1977). Railroads delivered Appalachia's natural resources to national markets and strengthened local economic ties with more urbanized areas of the country. Local farmers used railroads to deliver their products to market and import industrial farming supplies and machinery. The commercial livestock and timber industries expanded rapidly as a result of the penetration of railroads into north-central West Virginia, leading to mass deforestation of the region's virgin forest by the late $19^{\text {th }}$ century (Lewis 1998).

During this time of immense societal change, more and more West Virginia residents were forced to supplement their increasingly constricted self-employment with at least part-time wage labor in coal mines, logging camps, and railroads (Salstrom 1995). With the state’s forests almost completely obliterated by logging and control over its mineral resources resting in the 
hands of a few corporations, Appalachia's earlier subsistence economy and agrarian lifestyle gave way to dependence on wage-labor employment in capitalist enterprises and increasing reliance on manufactured goods.

Although north-central West Virginia and its residents have long been integrated into the mainstream U.S. socioeconomic system, the area remains part of a peripheral economic region from which raw materials are extracted to support core areas of capital and commerce (O’Brien 2001; Fisher 1993). For many local people today, producing food for household consumption remains an important part of piecing together a livelihood that includes a wide range of economic activities, both within and outside the market system. As a means of facilitating the conservation of cultural heritage, household food production also helps maintain the cultural and place-based difference manifested in a particular way of life. For West Virginians, this cultural and economic heritage includes a local culinary toolkit of household agriculture, animal husbandry, hunting, and foraging. My research examines how these local cultural traditions and diverse economic activities articulate with the hegemonic food culture and its ethical consumption-based counterparts in the United States today. 


\section{Chapter IV: Methodology}

\section{Methodological Framework}

I employed qualitative research methods, including surveys, semi-structured interviews, and ethnographic observation, to collect and analyze data for this research. Qualitative methodologies in geography are intended to illuminate individual experiences and social processes (Winchester 2005: 3). Thus, researchers often turn to qualitative methods when seeking to answer questions about the relationships between phenomena and places, and the behaviors and experiences of individuals and their positions within social structures (Winchester 2005: 5).

Qualitative research embraces the possibility of multiple meanings and interpretations rather than expecting to pin down a “correct” or “objective” answer. Qualitative methodologies help researchers to “capture the richness of context-dependent sites and situations” (Baxter \& Eyles 1997: 505) and present opportunities for members of marginalized groups to express viewpoints that are not widely heard (Dunn 2005). In using qualitative methods to explore the behaviors, motivations, and actions of individuals, researchers study participants’ roles as members of specific communities rather than as representative informants in a more abstract sense (Mullings 1999).

\section{Sampling}

During six months of fieldwork conducted throughout the summer and autumn of 2010, I created a sample of 30 participants in 23 households in north-central West Virginia. I used a purposive sampling method to recruit participants who engage in different types of food provisioning activities, e.g. vegetable gardening, fruit production, livestock rearing, herb cultivation, foraging wild plants and fungi, and hunting wild game and fish. Purposive sampling 
is intended to obtain a particular group for study on the basis of specific characteristics possessed by members of that group. This sampling method helps to connect the researcher with information-rich participants who can shed light on issues of central importance to the study (Hay 2005: 292). I also employed snowball sampling to broaden my sample to include neighbors and associates of established participants.

I located participants via several sources: Some are former members of a now-defunct rural cooperative buying club; others are vendors and organizers at local farmer's markets; some are members of a local Master Gardener's association; and others are employees of West Virginia University’s Extension Service. Upon making initial contact via telephone, e-mail, or in person, I gave potential participants a copy of my IRB cover letter, which informed them about my identity, the purposes of my research, and their rights as participants. At that time, I requested an approximately one-hour face-to-face meeting with informants who agreed to participate. Most of these meetings were one-on-one interviews in which only the participant and I were present. In several cases, however, I interviewed sets of domestic partners together in pairs, making for a three-way conversation between two participants and me.

\section{Surveys and Interviews}

For this research, I relied primarily on oral (i.e., interview-based) qualitative methods namely, surveys and semi-structured interviews — supplemented by ethnographic methods. I will discuss each of these methods in turn here, providing a general overview of their uses in social science research and explaining how I specifically employed each method in my work.

As Winchester (2005) explains, “Surveys are undertaken to obtain information from and about individuals that is not available from other sources” (7). For this research, I created a household economic survey (See Appendix A, p. 60) which allowed me to access specific 
demographic information about each of my informants and to compile a standardized set of data regarding all food-provisioning activities undertaken within my sample. Following McGuirk \& O’Neill's (2005) suggestions for questionnaire design and format, I sought to formulate survey questions that were precise and unambiguous, and which clearly communicated the intent of the inquiry.

I began each participant meeting by administering the first half of the survey, which gathered information about the quantities and varieties of foods produced for consumption within each participant's household, and the significance of those foods in participants' overall diets and household food budgets. After implementing this part of the survey, I turned to a semi-structured interview format for the central and lengthiest portion of each meeting.

Interviews offer several strengths as a method of qualitative research: They allow the researcher to access information about complex factors that motivate behavior; and to collect diverse opinions and understandings that may help to reveal disagreement as well as consensus within a group on a certain issue (Dunn 2005). A semi-structured interview format provides the researcher with the structure of predetermined questions and themes, yet allows for flexibility in how issues are addressed. Questions in a semi-structured interview are “content-focused and deal with the issues or areas judged by the researcher to be relevant to the research question” (Dunn 2005: 88). Questions are presented in such a way as to allow flexible responses by informants that may take the conversation in unexpected directions. In this way, informants maintain some power in directing the interview toward information they consider to be relevant (Dunn 2005).

In preparation for my fieldwork, I created an interview guide (see Appendix B, p. 63) that identified key questions, concepts, and themes to discuss during interviews. I formulated a series of specific primary questions with nested sets of secondary questions to use as prompts during 
the course of each interview. I began the interview segment of each meeting by asking how the participant had gained the skills and knowledge he or she possesses in regard to food provisioning. This line of questioning brought up such topics as family traditions, cultural heritage, and educational resources. Subsequent interview questions probed the participant’s motivations for producing food, including economic, cultural, political, and ideological motives; and his or her views of and relations to food systems on local, regional, national, and global scales, including the mainstream U.S. agro-food system as well as contemporary agro-food movements that present themselves in contrast to that system.

I finished each meeting by administering the second part of the household economic survey, which collected demographic data about participants such as household composition, residential status, educational background, employment history, and income sources and levels. I considered the possibility that some participants might be reluctant to share information about their income and employment, so I saved those questions for the end of each meeting. In this way, I sought to establish trust and rapport with my participants by opening our conversations with simple, easily answered questions before broaching more pointed questions that required informants to share potentially sensitive personal information or reflect upon complex issues (Dunn 2005).

\section{Ethnography and Positionality}

Kearns (2005) argues that qualitative approaches allow for the consideration of human experience and acknowledgement of researchers' relationships with the people and places they study (194). Thus, rigorous social-science research must grapple with questions of power relations between researchers and their subjects based on the positionality of each party in relation to the other (Mullings 1999). This type of research demands a high level of reflexivity 
on the part of the researcher in order to acknowledge and deal with her subjectivity and biases. A researcher's knowledge is necessarily partial due to her positionality, both to the research and more generally as an individual with particular perspectives and views.

The implications of a researcher’s positionality for gaining access to certain types of knowledge and information are significant when considering whether the researcher is perceived as an “insider” or “outsider” vis-à-vis his or her research subjects. As Winchester (2005) points out, qualitative researchers must be willing to confront “...problems of positioning of the author in relation to the subject of the research” (9). She goes on to warn that “...researchers who are personally involved, for example by researching the community in which they grew up, may find it hard to wear their 'community' and 'researcher' hats at the same time” (Winchester 2005: 9).

As a native resident of West Virginia who provisions food for consumption within my household, I am positioned in significant ways as an insider to my research topic and subjects, with all the benefits and drawbacks that come with that positionality. However, to reduce my identity as a researcher to the aforementioned attributes ignores other facets of my personhood that influence my perceptions and interpersonal relations. Gender, class, ethnicity, and age are only some of the more readily identifiable facets of my identity that might have influenced relations with my research subjects as well as the type of information I was able to access. Mullings (1999) argues that the insider/outsider binary is a highly unstable concept in view of the dynamism of positionalities through time and space. How a researcher represents herself can help or hinder building trust and cooperation with informants. Self-representation by the researcher presents an opportunity to maneuver within the insider/outsider binary in order to create a space where the researcher and subject can view each other as relative equals (Mullings 1999). 
With these caveats in mind, I maintain that my familiarity with the study area and research topic was extremely helpful in building trust and establishing rapport with my informants. My personal experiences as a self-provisioner also equipped me with an initial stock of knowledge that helped to generate productive avenues of inquiry throughout the research process. Taking advantage of opportunities to engage in participant observation (e.g., the anecdote related in the introduction of this paper) also enabled me to negotiate the line between “insider” and “outsider” vis-à-vis my research subjects.

According to Winchester (2005), “[P]articipant observation is the means or method by which ethnographic research is undertaken” (9). Kearns (2005) defines the goal of participant observation as “developing understanding through being part of the spontaneity of everyday interactions” (195). Such an approach to fieldwork can facilitate meaningful relationships between the researcher and her subjects and helps the researcher to develop deeper understandings of the research context (Winchester 2005: 9). As a researcher examining social formations and processes occurring within my own locality, my role became that of "participantas-observer” (Kearns 2005: 196).

Most of my meetings with participants took place in their homes. When this was not feasible, I interviewed participants at their places of work, including local farmer's markets. Interviewing informants in their homes and workplaces enabled me to observe the environmental and social circumstances of their daily lives. Analyzing these observations in combination with data compiled from interviews and surveys allowed me to compare and contrast participants’ expressed motivations and desires regarding their food production and consumption activities with the socioeconomic and environmental contexts in which they live and work. This aligns with Kearns’ (2005) discussion of observation as a research tool that provides researchers with 
“complementary evidence” and "additional descriptive information before, during, or after other more structured forms of data collection” (193).

\section{Coding and Analysis}

I administered the household economic surveys orally, writing down participant responses to each question on paper copies of the surveys. Rather than relying solely on written notes for the longer interview portion of these meetings, however, I made audio recordings of all participant interviews, which I later transcribed. In addition to the interview transcriptions and survey responses, I also took field notes during each meeting with participants. I noted observations about the material circumstances in which each interview took place, pertinent comments made by participants outside the formal interview setting, and thoughts or questions that struck me at the time. I drew upon these field notes as memory aids during the transcription process, which I completed as soon as possible after each interview had taken place, always within a week.

I used Microsoft Excel and Microsoft Word software to code the data I had collected. I created a series of Excel spreadsheets to compile and organize the survey data in a logical and accessible manner. These spreadsheets included detailed lists of all the foods my participants reported self-provisioning, and the numbers and percentages of participants within the overall sample who provision each type of food (See Tables 1 through 7, p. 4X-5X). I also used Excel spreadsheets to organize and code the demographic data I had collected, including: household size and composition; highest level of education completed by each participant; acreage of participants’ residential properties; their residential histories; annual household incomes; sources of income; number of hours each participant devotes to food provisioning weekly; and food shopping habits. 
I used Microsoft Word to sort and code interview responses under the rubric of several broad themes: food provisioning skills and heritage; main motivations for food self-provisioning; presence or absence of expressed financial motivations for self-provisioning; the role of ethics in food production and consumption habits; and food shopping preferences and motives. I colorcoded participant responses to questions pertaining to each theme in order to sort and analyze the types of responses participants gave. For instance, on the subject of food shopping, I color-coded participants’ expressed concerns for: price and convenience; variety and quality; locality; and organic production methods. Using these techniques, I analyzed interview transcriptions and field notes for both manifest and latent content. 


\section{Chapter V: Research Findings}

All participant households in this sample cultivate vegetable gardens. They reported growing 38 types of vegetables in all. More than $75 \%$ of participant households grow the same core set of garden crops: tomatoes, snap beans, sweet corn, onions, chili peppers, and potatoes. Lettuce, sweet peppers, and squashes are grown by more than $60 \%$ households. In addition to eating fresh vegetables in season, all participants process and preserve (i.e., freezing, canning, drying) some portion of their garden's produce. More than half of participants reportedly grow, process, and preserve all or most of the vegetable matter consumed year-round within their households. See Table 1 (p. 53) for a complete list of vegetables grown by participants in this sample, and the number and percentage of participant households that grow each type of vegetable.

All households but one (96\%) cultivate fruits and berries (15 varieties in all), the most common being apples and blueberries. Three participant households (13\%) cultivate nut trees (four species in all). See Table 2 (p. 54) for a complete list of fruits, berries, and nuts grown by participants in this sample, and the number and percentage of participant households that grow each type of fruit, berry, and nut.

Ten participant households in this sample (43\%) grow field crops, some of which are used to feed themselves and their families, others as fodder for participants' livestock and/or for sale to other local livestock farmers. See Table 3 (p. 55) for a complete list of field crops grown by participants in this sample, and the number and percentage of participant households that grow each type of field crop.

Nineteen participant households (83\%) cultivate culinary and/or medicinal herbs, 18 varieties of culinary herbs in all (basil, oregano, and parsley being the most popular) and more 
than a dozen varieties used to make health and beauty products. See Table 4 (p. 56) for a list of culinary and medicinal herbs grown by participants in this sample, and the number and percentage of participant households that grow each type of herb.

Seventeen participant households in this sample (74\%) raise livestock, the most common being chickens. See Table 5 (p. 57) for a list of the livestock raised by participants in this sample, and the number and percentage of participant households that raise each type of livestock.

Sixteen participant households (70\%) reported fishing and hunting wild game. More than half of participant households (52\%) fish for seven types of wild-caught fish in all, the most popular being bass and trout. More than half of participant households (52\%) also hunt deer, by far the most popular game animal in this sample. Five participant households (22\%) hunt other types of wild game (i.e., squirrel, rabbit, turkey, quail, grouse). See Table 6 (p. 58) for a list of the game hunted and fished by participants in this sample, and the number and percentage of participant households that fish or hunt each type of game.

Nineteen participant households (83\%) reported foraging wild plants and fungi. More than half of participant households (52\%) forage wild fruits and berries (eight varieties in all), particularly blackberries, which grow abundantly in the study area. Four participant households (17\%) forage edible tree nuts (three types); and 14 households (61\%) forage one or more of the following items: medicinal herbs, wild greens, ramps, maple sap, and edible mushrooms (nine varieties). See Table 7 (p. 59) for a list of items foraged by participants in this sample, and the number and percentage of participant households that forage each item. 


\section{Chapter VI: Analysis}

At first glance, these shared food provisioning strategies may give the impression of homogeneity within the sample. To the contrary, however, the process of data coding and analysis revealed the existence of wide range of economic strategies, material circumstances, and political views amongst participants in this research.

I coded the data for both manifest and latent content, using survey and interview questions as starting points to search for themes of continuity and difference within the overall data set. I began by categorizing each participant according to the food-provisioning activities he or she undertakes (e.g., vegetable gardening, fruit production, culinary herb cultivation, medicinal herb cultivation, fishing, specific foraging activities, types of game hunted, types of livestock raised). I also noted which participants adhered to specific production methods (e.g., organic gardening, square-foot gardening, seed saving, etc.). I arranged participants with similar provisioning strategies together into loose groups.

Next, I examined participants' socioeconomic circumstances, including employment characteristics (e.g., part-time wage labor, full-time wage labor, self-employed/entrepreneur, retiree, etc.); annual household income; residential history; and rural v. urban residence. I also noted how many hours per week each participant spends on average provisioning food for themselves and their families; whether or not they articulate their food production activities with the market economy (i.e., commercial v. noncommercial food production); and whether or not they engage in non-monetary economic exchanges such as barter. This allowed me to group participants into categories based on their financial resources, time-management strategies, and household economic circumstances. 
I turned next to an examination of participants’ food consumption habits, starting with the types of stores they frequent for household food shopping. I grouped together participants who typically shop at conventional supermarkets (e.g., Walmart, Kroger); those who prefer to shop at locally owned and operated food stores (e.g., IGA, Shop 'n' Save); those who prefer to buy organic and fair-trade foods; regular farmer's market customers and/or CSA members; those who order bulk items such as dry goods via alternative (e.g., cooperative, direct-delivery, membership-only) suppliers; and those who seek out direct local suppliers for meat, eggs, and dairy products.

In addition to examining participants’ material relations with larger agro-food systems via their household consumption habits, I also analyzed how participants viewed those systems and their relationships to them. I coded interview transcripts for concerns about specific agrofood issues, including: use of agricultural chemicals (e.g., fertilizers, insecticides, herbicides, fungicides); chemical processing and food additives; animal rights and welfare; land management; climate change; pollution; fossil fuel use; corporate consolidation of the food system; genetically modified (GM) organisms; labor rights; and government agriculture policies such as agricultural subsidies and food safety regulations. I also noted whether participants expressed optimism or pessimism about the future of U.S. agriculture, and how those attitudes articulated with participants’ expressed concerns and views about the agro-food issues listed above. The relative weight and breadth of concerns and interests expressed by different participants gave me important insights into the differently nuanced knowledge that helps to shape participants' understandings of food production and consumption. I drew upon these statements of concern to categorize participants based on their stated ideological and political motives for particular self-provisioning activities and consumption strategies. 
My analysis thus emanates from and remains centered in the data provided by

participants themselves, while also reflecting my interpretations of that data. It encompasses both material and ideological issues that affect participants’ food-provisioning strategies as well as their views and understandings of their own actions and of larger food systems in which they remain embedded. I have identified four main categories, or types, of self-provisioners within the overall sample. Members of each of these groups possess material and ideological similarities with one another while also exhibiting demonstrable differences from members of other groups.

\section{Group 1: “The Back-to-the-Landers"}

The first group I will discuss is “The Back-to-the-Landers,” which includes eight participants in seven households. Most members of this group moved to rural West Virginia as young adults in the 1970s and '80s. At that time, more than a million young members of the counter-culture migrated from American cities and suburbs to rural areas of the United States and Canada in what became known as the "back to the land” movement (Jacob 1996). Many of these young homesteaders chose to settle in West Virginia due to the state's low population density, rural character, and strikingly low land prices compared to other areas of the eastern United States. As one "Back-to-the-Lander” in this sample remarked, "I got a whole house and a hundred acres here for what I would've paid for a row-house in Baltimore.”

Members of this group approach food production and consumption as elements in an overall household subsistence strategy that prioritizes personal security and independence. Issues of control and safety are central to this group’s approach to food production and consumption. "I want to know what my food source is, where it comes from, [and] what's in it,” replied one member of this group when asked to explain her main motivations for producing food. 
Members of this group spend 10 to 15 hours a week on average producing, processing, and preserving food, yet these activities remain largely disarticulated from the market economy. Only one "Back-to-the-Lander" sells produce commercially, and then only if he happens to have a surplus of a certain crop. For members of this group, household consumption needs are the primary motivator for food production.

All members of this group are skillful and committed gardeners and orchardists who grow a wide variety of vegetables and fruits. All grow culinary herbs, and most also grow medicinal herbs. Almost all members of this group raise livestock, most commonly chickens, which provide eggs and meat. While some members of this group sell extra eggs to friends and neighbors, as with the products of their gardening efforts, poultry is kept primarily for consumption within their own households. The same holds true for other livestock: Some members of this group occasionally sell surplus beef, pork, or chicken to friends or neighbors, but animals are slaughtered first and foremost for household consumption.

While most households in this group occasionally consume wild fish and game, hunting and fishing do not occupy central roles in this group's food provisioning strategies. Only one member of this group can be described as an enthusiastic hunter and fisherman. Similarly, while most members of this group forage some wild plants and fungi, their foraging activities are limited in weight and scope. They tend to focus on wild berries, which are easy to preserve and freeze, and common native plants used in herbal medicines. One possible explanation for this group’s general lack of interest in hunting and foraging is that most "Back-to-the-Landers" grew up in cities, towns, and suburbs, having moved to rural West Virginia only as adults. They are therefore less likely to have been raised in a strong hunting and gathering culture such as we enjoy in rural Appalachia. 
There is cohesion within this group's food consumption habits as well as its food production strategies. Members of this group have some of the lowest annual household incomes in the overall sample. Only one is currently a full-time wage laborer; the rest cobble together livelihoods from various combinations of part-time wage labor, artisanal production activities, entrepreneurship, and, in some cases, pensions. All members of this group but one reported household incomes below the state median of \$37,528 (U.S. Census Bureau 2010). These participants live comfortably but frugally, and food self-provisioning makes up no small part of their highly diverse household economic strategies. As part of the general ethos that initially drove hundreds of thousands of young people out of American cities and into the nation's rural hinterlands, these diverse economic strategies reflect the experiences of a certain section of the working class that decided to withdraw as much as possible from the labor force based on the idea that "better, more fulfilling work can be done outside the waged dynamic" (Carlsson \& Manning 2010: 931).

For participants with lower incomes, stretching the household food budget is particularly important. It makes sense, then, that members of this group tend to shop in bulk. Several are former members of a defunct rural cooperative buying club. Since its collapse, many of its members have become customers of Frankferd Farm Foods, a regional bulk and organic food producer, processor, and distributor based in southwestern Pennsylvania. Frankferd makes deliveries throughout Pennsylvania, West Virginia, and Ohio, and for these rural residents, the company's convenient local delivery schedule is as appealing as its wide variety of bulk items such as dried fruits, nuts, grains (including a line of flours and baking mixes grown and milled on the company's farmland); and a wide range of organic canned, frozen, and "convenience” 
foods. Frankferd's large organic selection is another factor in the company's appeal to these participants, most of whom are committed organic growers.

Still, this group's desire for control over what they eat extends beyond the mainstream industrial food system to embrace any and all foods that are produced outside their direct oversight. Even those participants who are willing to pay higher prices for certified organic foods tend to question the environmental impacts and overall accountability of industrial organic agriculture. Remarked one member of this group about the organic foods she buys from Frankferd and at local supermarkets, “Even though it says organic, I don’t know that you can trust that 100 percent.”

For meat and animal products not produced within their own households, members of this group prefer to seek out local producers rather than shopping at commercial supermarkets. In addition to their overarching concerns for control and accountability, the group's preference for local meat, eggs, and dairy products springs from two related issues: On one hand are concerns for animal welfare (“If I eat [meat] in a restaurant,” said one member of this group, “I can’t help but think about how the chicken was raised, what kind of life the cow had.”); on the other are considerations of quality, freshness, and taste. Members of this group consider store-bought meat to be qualitatively inferior to locally raised meat. As one participant put it, “I just don’t do store hamburger.”

In keeping with their diverse livelihood strategies, non-monetary economic exchanges are common amongst members of this group. Many of these "Back-to-the-Landers" barter their labor and its products (e.g., home-grown food, crafts, artworks) with other local farmers and artisans. For instance, two members of this group work at a local greenhouse each spring in exchange for seedlings and plants. Gardeners trade fresh vegetables for local meat and eggs. One 
participant who milks a dairy cow has no shortage of thirsty friends and neighbors eager to trade goods and labor in exchange for fresh milk.

Members of this group share ideological as well as material similarities that influence the forms and functions of their food provisioning strategies. They are starkly pessimistic about the future of American agriculture and the viability of the global food system. During our interviews, “The Back-to-the-Landers” warned time and again of dark days ahead for agriculture on national and global scales. They predicted impending food shortages, widespread public health crises, and the imminent collapse of the global industrial agriculture system. One participant compared the U.S. food system with the U.S. financial system — centralized, consolidated, corporatized — conjuring up specters of the 2008 financial crash with the warning, “We've seen other big corporate things get so big [that], if they fail, it’s a huge failure. I don't see why that couldn't happen to the food industry.”

Some of these doomsday prophecies took on an outright apocalyptic tone. One dedicated seed saver spoke gravely about the dangers of genetically modified food crops, which he believes will “destroy our food production in the world.” He went on to say, “The future is gloom. If you believe in God, that's day’s comin', and it's not far.”

With such profound misgivings about the global future of food production, is it any wonder that these participants seek to disconnect their food provisioning strategies from the mainstream agro-food system? Is it any wonder, either, that they are hesitant to identify too closely with any of today’s trendy alternative agro-food movements, which ultimately remain dependent upon formal markets and commodity exchange? “The Back-to-the-Landers” chafe against anything they perceive as potentially deepening their dependence on a faceless institution, no matter how benign it appears, especially for something as essential as food. "I feel 
bad for the people in the city that are totally dependent on goin' to the grocery store,” pondered a soft-spoken, white-bearded man as we sipped tea at his kitchen table. "If things got really bad for food production, I think I'd have a chance of survivin'. I bought a generator. I got an oil lamp on the table. I can cook [with gas]. I'm ready to go.”

\section{Group 2: “The Hobbyists”}

The second group I will discuss is “The Hobbyists,” which includes six participants in six households. Unlike the other three groups within this sample, members of this group did not express strong political, economic, or ideological motivations for food self-provisioning. They view food production and consumption in fairly apolitical terms when compared to the rest of this sample. Rather, they approach food production as a beloved hobby and pleasurable pastime. Members of this group are enthusiastic gardeners who are quick to sing the praises of plants, nature, and the outdoors. Most were born and raised in the study area, and some even live on the land where they grew up. Familial and regional heritage, then, plays a large role in this group’s food production and consumption activities.

Most members of this group are retirees who derive modest but comfortable incomes from pensions, investments, and, in some cases, part-time wage labor. They do not identify as belonging either to an American farming tradition or to any alternative agro-food movements. Rather, they explain their self-provisioning activities as enjoyable pastimes that provide an appealing combination of healthy exercise, tasty food, and an outdoor-oriented lifestyle that reflects and honors their cultural heritage. 'I've been doin' this ever since I was old enough to pick up potatoes out of my grandpa's field,” said one member of this group. 'It's just somethin' I’ve always done. I just like to do it.” 
Members of this group are all over the map in terms of vegetable gardening: They grow the widest variety of vegetables of any group in this sample and enjoy experimenting with different vegetables from one year to the next. Likewise, members of this group cultivate a wide variety of fruits, berries, and nuts, motivated as much by the pleasure of growing new and interesting species than by hopes of a fine harvest.

Herb cultivation reveals an internal cultural divide within this group. Two members grow no herbs, and a third grows only basil. All three of these participants are older male retirees for whom herbs are largely absent from their culinary "toolkits.” In contrast, other members of this group grow an array of culinary herbs as well as some medicinal herbs with which they make health and beauty products (e.g., soaps, teas, tinctures) for use within their households and to share with friends and relatives.

As with herbs, this group is divided when it comes to hunting and fishing: Half of its members neither hunt nor fish, while the other half (all middle-aged men) are enthusiastic hunters and fishermen. Foraging is a common practice throughout this group: All members forage, some for several edible mushrooms as well as that odiferous Appalachian springtime favorite, ramps. Hunting and foraging are vibrant elements of West Virginia's culinary heritage, and these tradition-oriented participants are helping to keep these practices alive in the $21^{\text {st }}$ century.

"The Hobbyists" raise the fewest livestock of all groups in this sample. Five out of six members of this group raise no livestock except, in one case, honeybees. One member of this group raises laying hens, stocks a pond with bass and catfish, and occasionally raises pigs for household consumption. Interestingly, this participant is the only "Hobbyist” who prefers to buy 
meat and dairy products from local farmers. All other members of this group shop for meat, eggs, and other dairy products at conventional supermarkets.

Also in contrast with “The Back-to-the-Landers,” most members of this group do not adhere to organic growing techniques, nor did they express much interest in or awareness of contemporary agro-food movements such as locavorism or fair trade. Rather, they contrasted their interest in producing food with a general lack of attention paid to food by society at large. “There's not a lot of people who [grow their own food] anymore. I think they just want to go to town,” said one member of this group. "It’s just priorities.”

Thus, “The Hobbyists” position themselves as members of a cultural minority who, in contrast to most Americans, are interested in growing food, eating a healthy diet, and getting outdoor exercise. These distinctive characteristics of the physical labor involved in food production, rather than concerns about ethical consumption, are the prime motivators for this group’s household food production activities.

\section{Group 3: “The American Farmers”}

The next group in my sample includes eight participants in five households. Mostly local West Virginians, members of this group share certain traits with “The Hobbyists,” in that their food provisioning strategies reflect local cultural traditions. Yet, members of this group also associate themselves with American farming in a broader sense. Defenders of American agriculture, they identify their own food production activities as part and parcel of the mainstream U.S. food system, and they take pride in that association. In a word, I would describe members of this group as "traditional” American farmers in their overall approach to food production and consumption. Thus, I refer to them here as “The American Farmers.” 
Members of this group approach food production with an entrepreneurial mindset that sets them apart from the previous groups I have discussed. One participant in this group operates a commercial fruit orchard. All the others are cattle farmers. Two of the latter households manage small herds of approximately one dozen cattle; the other two maintain larger herds of 50 and 100 cattle, respectively. All of the cattle farmers grow hay for commercial sale as well as to feed their own livestock; and two households in this group grow commercial field corn. Two households raise laying hens and sell fresh eggs; and one of these households also practices aquaculture, raising trout, bass, and catfish in specially-constructed freshwater ponds.

Two households in this group include school-aged children who are involved in local chapters of 4-H. Each year, these children complete agricultural projects as part of their 4-H requirements, such as raising livestock for auction at the county fair or growing a market garden. Earnings from such projects can be substantial: In one household they form the basis for each child's college savings fund.

All households in this group cultivate vegetable gardens, but they grow a more limited variety of vegetables than do other groups in this sample. Rather than growing small amounts of many different crops for household consumption, they tend to focus instead on larger-scale production of a few main crops. One household in this group sells tomatoes, peppers, potatoes, and onions at a local farmer's market and to private customers. Another household sells sweet corn at a roadside stand. Three households in this group consume home-grown vegetables in season but rely mainly on store-bought produce out of season. The other two households include husband-and-wife farming teams whose food production activities split along gender lines: The men focus on livestock production while the women produce, process, and preserve garden vegetables for year-round consumption within their households. 
Except for the commercial orchardist, members of this group cultivate few fruits. In fact, this group includes the only household in the entire sample that grows no fruit. Likewise, members of this group grow fewer herbs than most other participants in the sample: Two households grow no herbs, and a third cultivates only basil and oregano. The other households in this group grow some common culinary herbs, and one participant has recently begun cultivating ginseng for commercial sale. With that exception, no one in this group cultivates medicinal herbs.

Neither is foraging a common practice in this group. The ginseng cultivator also hunts that plant in the wild, but he forages no wild food plants. Two other households do no foraging, and the others forage only a few common and easily identifiable items (i.e., blackberries, elderberries, morels). Members of this group are more apt to hunt than forage. Most are local West Virginians who grew up hunting. Four out of five households in this group hunt deer, and one also hunts squirrel and game birds. The latter is the only household in this group that catches wild fish.

Households in this group exhibit a financial pattern common amongst American farming families, with one or both spouses holding full-time off-farm jobs in addition to their farm work. In one household in this group, both spouses are now old enough to receive Social Security benefits, so the wife has recently scaled back from full-time to part-time employment. The husband in this household is a self-employed cattle farmer. This couple derives a modest household income mainly from Social Security benefits supplemented by the wife's wages as well as sales of cattle, corn, and hay from their 127-acre farm.

All other members of this group are full-time white-collar employees of private enterprises or government institutions. All hold college degrees, making them amongst the most 
highly educated participants in this sample. With annual household incomes of more than $\$ 100,000$, they are some of the wealthiest participants in this sample, too.

Because they are producing surpluses for commercial sale as well as provisioning food for their own households, this group devotes more time to food production than any other group in this sample. The orchardist and self-employed cattle farmer both work 40 hours a week at farming (the former in addition to a full-time job). The remaining group members each spend between 15 and 20 hours per week at farming in addition to their full-time jobs. Particularly busy times in the agricultural cycle, such as calving, planting, and harvest seasons, demand even more labor time from these industrious participants.

Members of this group earn significant amounts of money from their food production activities, but most of that money is invested back into their farms. Cattle are lucrative commodities, but cattle farmers in this sample tended to emphasize not the earning potential of their operations, but, rather, the fact that they are able to "break even” with livestock. Even the participant with the largest (100-head) herd, whose beef sales gross $\$ 25,000$ a year, insisted that most or all of those earnings are absorbed by farm expenses and improvements. "This is a way for me to spend my salary," said another group member about her farming activities. She made this comment immediately after giving a detailed account of the number of calves, bushels of potatoes and corn, bales of hay, and dozens of eggs she sells each year.

That being said, members of this group are some of the most successful agricultural entrepreneurs in this sample, and their mindset about food production remains essentially economic. For them, food production can be a means for local families to their bolster household incomes and can provide opportunities for economic advancement. The following comment from one member of this group is a case in point: 
When I think about West Virginia farms, it seems to me they can help somebody improve their quality of life. Their kids might be able to go to school, or maybe the wife doesn't have to take a second job at minimum wage, because [farming] will give them a little extra chunk of change at the end of the year. It improves their quality of life.

Cattle farmers in this group supply their households with beef, but only one member of this group raises other meats consumed within her household. As mentioned above, only two out of five households in this group cultivate, process, and preserve most of the vegetable matter they consume throughout the year. Most members of this group rely instead on store-bought meats and vegetables. Their food shopping and consumption patterns are strikingly uniform: All shop for food at conventional supermarkets such as Kroger and Walmart. Price and convenience are their primary motives, and no one in this group expressed a preference for organic or fairtrade products.

Several members of this group did express support for farmer's markets, and one household sells vegetables at such a market. Two other group members have helped to organize and manage farmer's markets within the study area. Yet, no one in this group regularly shops at such venues. Nor do they seek out locally produced foods via alternative distribution services or direct trade with local farmers. Like those of "The Hobbyists," the highly conventional food shopping habits of "The American Farmers" contrast sharply with the concerns for ethical consumption expressed by “The Back-to-the-Landers” and, as we shall see, the fourth group I will discuss below.

“The American Farmers" share certain ideological similarities as well as common food production and consumption strategies. As mentioned at the beginning of this section, they identify themselves as American farmers and locate their farming activities within a general tradition of American agriculture. They express pride in and support for American farmers, 
amongst whom they count themselves. Perhaps, then, it should come as no surprise that, in sharp contrast to “The Back-to-the-Landers” (and, to a lesser extent, “The Hobbyists”), “The American Farmers” express optimism about the future of U.S. agriculture. After all, it is a system that seems to work well for them.

\section{Group 4: “The Movement”}

The final group I will discuss includes eight participants in five households. Members of this group support and identify with one or more of the contemporary agro-food movements that present themselves as alternatives to mainstream agriculture. We can view this group’s actions and viewpoints as "representing” such movements within this sample. Thus, I refer to them here as “The Movement."

Members of this group identify themselves primarily as educators whose mission it is to inform the public of the benefits and viability of concepts such as organic agriculture, local and regional “foodsheds," and fair trade. This group views food production and consumption as potential sites of resistance that present opportunities for public education and activism. They identify themselves as counter-hegemonic actors who challenge the status quo by performing an interrelated set of food production and consumption activities that they understand to be healthful and sustainable, in contrast to the mainstream food system, which they view as unhealthy and unsustainable.

All households in this group cultivate vegetable gardens, but, like “The American Farmers,” most members of “The Movement” purchase rather than produce most of the vegetables they consume out of season. One household in this group grows a wide array of fruits and berries (14 types in all), but other group members cultivate only a limited variety of fruits. At first glance, then, this group appears to have fruit and vegetable consumption habits similar to 
those of "The American Farmers," in that both groups tend to purchase rather than produce the majority of fruits and vegetables consumed within their households year-round. However, further investigation reveals significant differences in these group’s fruit and vegetable consumption patterns. Like “The Back-to-the-Landers,” members of “The Movement” prefer to buy organic and locally produced fruits and vegetables, and they are willing to higher prices more for these items. Members of “The Movement” also consider seasonality to be an important factor when choosing which fresh fruits and vegetables to purchase at a certain time of year. As one participant put it, “I don’t buy strawberries in winter. I’ll eat something like that when it’s fresh and I can get it at the farmer’s market.”

This group’s enthusiasm for herbs also aligns them with “The Back-to-the-Landers.” One couple in "The Movement” operates a home-based agricultural business based on medicinal herbs, herbal health and beauty products, private health consultations, and herb production workshops. These two participants cultivate an extraordinary variety of culinary and medicinal herbs. Other members of “The Movement” are keen on herbs as well. All households in this group cultivate an array of culinary herbs as well as one or more herbs (e.g., lavender, lemon balm, Echinacea, etc.) used to make health and beauty products such as teas, tinctures, soaps, salves, and scented oils.

Like “The Hobbyists,” members of “The Movement” do not raise many livestock animals. (“The Movement” includes one of only two vegetarian participants in the overall sample. The other is a "Back-to-the-Lander.”) Three households in this group raise no livestock except, in one case, a pond stocked with trout, and, in another case, a hive of honeybees. One farmer's market vendor raises laying hens and sells fresh eggs as well as vegetables. The only prominent exception to this group's general dearth of domestic animals arrives in the form of a 
self-employed farmer who raises beef cattle and pigs for household consumption and commercial sale at farmer's markets and to CSA subscribers. This participant also raises dairy cows to supply his household with milk products, and works with draft horses on his farm. He grows hay and oats for livestock fodder.

Members of “The Movement” are enthusiastic foragers. All gather wild edible plants, and several forage wild mushrooms and medicinal herbs. Three households in this group fish for wild-caught species such as trout, bluegill, and bass; but hunting is much less common for these participants than for "The Hobbyists” or "The American Farmers.” Only two households in this group hunt, and only for deer.

While not as high as those of “The American Farmers," all households in this group earn annual incomes greater than West Virginia’s median of \$37,528 (ibid.). Also like “The American Farmers,” members of this group are highly educated; all are college graduates. Three members of this group are retirees, former full-time workers who receive pensions and/or Social Security benefits. Three households operate home-based agricultural businesses, two of which include members who also hold off-farm jobs. One household in this group consists of several young adults who live together in an intentional religious community. They devote their time to volunteer work in the local area and host religious retreats on their rural property, which is owned and overseen by a regional diocese.

As discussed above, most members this group articulate their household food production activities with the formal market economy. “The Movement” includes several agricultural entrepreneurs who produce surpluses for commercial sale in addition to provisioning their own households. These participants devote a substantial amount of time to food production, between 20 and 40 hours a week. Members of this group who are not commercial farmers spend less time 
producing food, between 10 and 15 hours a week on average, but this remains a significant allocation of daily labor time and energy.

Members of “The Movement” view food production and consumption through an ideological as well as an economic lens. By participating in farmer's markets, CSAs, and direct trade with local farmers, and by focusing their food consumption habits on seasonally available items produced in West Virginia and the surrounding region, members of this group actively support the growth and development of a local food system. They defend such a system as beneficial to the local economy (mainly by creating local jobs and business opportunities) and the global environment (primarily by reducing the consumption of fossil fuels used to transport food long distances). Due to concerns about sustainable land management and use of agricultural chemicals, all members of this group practice and promote organic agriculture in their food production activities as well as their consumption habits.

Their involvement in burgeoning agro-food movements lends these participants a hopeful outlook toward the future of American agriculture — or, more specifically, the kinds of alternative agriculture in which they are involved. "I think the local food movement and farmer's markets have to be the primary source for educating the consumer and the public," said one agricultural entrepreneur, civic-minded educator, and tireless local-food advocate. "My vision is that everyone who can grow [food], does... and my mission is to educate as many people as I can about healthy eating.” Said a fulltime farmer and father of four, “I really feel like I’ve dedicated my life to this — to having a model for a healthy food system.”

\section{Summary}

Figure 2 (p. 43) lists some of the specific attributes identified within each of the four subgroups in this sample. The figure is arranged along two axes: The horizontal axis represents 
the extent to which each group articulates their food production activities with the formal market economy, with market articulation increasing from left to right along the axis; and the vertical axis represents the extent to which members of each group expressed concerns for and awareness of issues of ethical consumption, with such concerns and awareness increasing from bottom to top along the axis.

\begin{tabular}{|c|c|c|}
\hline ह & $\begin{array}{l}\text { The Back-to-the-Landers } \\
-\quad 8 \text { participants, } 7 \text { households } \\
-\quad \text { Non-local } \\
-\quad \text { Organic growers } \\
-\quad \text { Little hunting, foraging } \\
-\quad \text { Low incomes } \\
-\quad \text { Barter, direct trade } \\
-\quad \text { Local, organic, bulk shoppers } \\
-\quad \text { Focus on control, security } \\
-\quad \text { Pessimistic }\end{array}$ & $\begin{array}{ll} & \text { The Movement } \\
- & \text { 8 participants, } 5 \text { households } \\
- & \text { Non-local } \\
- & \text { Organic growers } \\
- & \text { Much herb production, foraging } \\
- & \text { Few livestock } \\
- & \text { High incomes, education levels } \\
- & \text { Local, organic shoppers } \\
- & \text { Focus on outreach, health, education } \\
- & \text { Optimistic }\end{array}$ \\
\hline & $\begin{array}{ll} & \text { The Hobbyists } \\
- & 6 \text { participants, } 6 \text { households } \\
- & \text { Local } \\
- & \text { Non-organic growers } \\
- & \text { Internal divisions re: herb } \\
& \text { production, hunting } \\
- & \text { Few livestock } \\
- & \text { Retirees } \\
- & \text { Conventional grocery shoppers } \\
- & \text { Focus on heritage, cultural traditions } \\
- & \text { Pessimistic }\end{array}$ & $\begin{array}{l}\text { The American Farmers } \\
-\quad 8 \text { participants, } 5 \text { households } \\
-\quad \text { Local } \\
-\quad \text { Non-organic growers } \\
-\quad \text { Little herb production, foraging } \\
-\quad \text { Much livestock, hunting } \\
-\quad \text { High incomes, education levels } \\
-\quad \text { Conventional grocery shoppers } \\
-\quad \text { Focus on entrepreneurship } \\
-\quad \text { Optimistic }\end{array}$ \\
\hline
\end{tabular}

Articulation with market

Figure 2. Subgroups within the overall sample. 


\section{Chapter VII: Discussion and Conclusion}

Conducting this research enabled me to successfully address the questions I set out to answer concerning the relations of food self-provisioners to the mainstream food system and alternative agro-food movements: As analysis of this data set demonstrates, the overall category of food self-provisioners encompasses individuals with a wide range of motivations, identities, and goals in relation to hegemonic and counterhegemonic food projects. However, there are limitations to this study that may have impacted its outcomes and which must be acknowledged here. One such limitation is the small size of my sample, which restricted the quantities and types of data I was able to collect and may have prevented certain information from being uncovered. Likewise, my choice of sampling methods (i.e., purposive and snowball sampling) may have created a narrower sample than is actually representative of the full range of food selfprovisioners in the study area. These sampling methods also might have led to an unrepresentative weighting of certain types of informants and information at the expense of others which remain unknown.

In addition to examining difference within the category of self-provisioners, it also is important to recognize shared attributes that serve to unite all of my participants under the rubric of self-provisioning. All participants in this research have in common certain emotional and intellectual approaches to the work of self-provisioning, regardless of their affiliations with the four subgroups I have discussed. All of my participants expressed high levels of enthusiasm for and intellectual curiosity about the work of self-provisioning; I was struck time and again by their eagerness to experiment and willingness to venture outside their comfort zones, physically and mentally. 
Producing food is a complex and uncertain task ill-fitted to those who shrink from the possibility of failure or who prefer to follow rigid schedules and rules. I heard no shortage of stories from my participants about their past failures and errors in judgment; yet no one seemed defeated those mistakes. To the contrary, I sensed real excitement when participants revealed their plans for future seasons, new ideas, and fresh knowledge. For these informants, food provisioning provides not only the material benefits of fresh, healthy food and physical exercise, but also offers the intellectual pleasures of learning and the emotional satisfaction of a job well done.

This point should not be taken lightly, for it demonstrates a core feature of the labor involved in self-provisioning and the relationship self-provisioners have to that labor: Selfprovisioning involves agency — the agency of autonomous subjects performing work that directly benefits themselves and their families, households, and communities. The work of selfprovisioning represents a distinctive kind of labor that exists outside the bounds of the capitalist economy. Consuming the products of their work — in the truest sense of the term, the fruits of their labor — allows my participants to experience and appreciate the real connections between production and consumption.

This positionality stands in sharp contrast to the fetishized commodity production and consumption of the hegemonic food system. By making atypical everyday choices about how to spend their energy, time, skills, and knowledge, food self-provisioners simultaneously reduce their contributions to and dependence upon that system. In this way, self-provisioner can be viewed as potential contributors to the development of a diverse economy that strengthens and promotes noncapitalist economic forms already in existence while also helping to envision and create those just coming into being. Regardless of the economic ties its practitioners maintain to 
the capitalist economy and hegemonic food system, their performances of the work of selfprovisioning involve them in a type of labor that lies beyond the sphere of capitalism.

However, it is not my goal here to suggest that the material practice of self-provisioning as performed in this sample necessarily represents an attempt to subvert or overturn the capitalist economic logic that drives the hegemonic food system. Rather, this research demonstrates that self-provisioners themselves hold a wide range of perspectives on whether or not selfprovisioning is a counterhegemonic act — or whether its nature is political at all. Indeed, my participants' approaches to food provisioning exist along a spectrum of articulation with food politics vis-à-vis the market economy: from active and politically motivated non-participation; to basically apolitical non-participation; to active but largely apolitical engagement; to active and politically motivated engagement.

Moreover, the political perspectives held by participants in this sample encompass, yet go beyond, the ethical consumption paradigm as discussed in the literature review section of this paper. Promoters of ethical consumption not only encourage us to consume alternatively; they suggest that such alternative forms of consumption demonstrate and enact a certain political perspective in regard to food. From there, it becomes all too easy to assume that this (ethical consumption-based) political perspective is the driving force behind any and all forms and relations of food production and consumption that fall outside the mainstream agro-food system. This work demonstrates otherwise, that the performance of a certain (non-capitalist) kind of work does not presuppose the existence of a certain (anti-capitalist) political consciousness. Indeed, this research shows that self-provisioners hold a range of perspectives on whether and how the work of self-provisioning is a political act of any kind, let alone whether and how it is a counterhegemonic one. 
The suggestion that self-provisioning can be a counterhegemonic political act rests not only upon its non-capitalist use and relations of labor, but also linkage to a strong anti-capitalist political consciousness. Ethical consumption, while promoting just such a political consciousness that (ostensibly) desires to challenge and subvert the hegemonic food system, has come up against a barrier formed by its relations (or lack thereof) to the actual work of food production. In order to move beyond simple economic prescriptions that supposedly guarantee the fulfillment of abstract standards of value, the ethical consumption framework must begin to rethink the relationship between particular kinds of consumption and forms of production in ways that promote and strengthen counterhegemonic relations of the latter as well as the former.

Food self-provisioning provides important insights into such a rethinking of consumption ethics. The work of self-provisioning requires its practitioners to reflect upon and take responsibility for the consequences of the production strategies and consumption choices they employ along each step of the cycle of producing and consuming food. In engaging with the totality of that cycle — not from the alienated, estranged vantage point of a capitalist wage laborer (and potential “ethical consumer”), but in a non-capitalist arrangement of labor in which work and surplus are self-determined — self-provisioners grapple with everyday decisions and concrete struggles that inform their specific understandings of what it means to ethically consume. With this in mind, we can begin to examine how the essential role of labor in selfprovisioning can provide opportunities to broaden and refine the framework of ethical consumption to include noncapitalist, potentially counterhegemonic forms and relations on both sides of the production/consumption divide. 


\section{References}

Barham, E. (2002). Towards a theory of values-based labeling. Agriculture and Human Values 19, 349-360.

Barron, E. (2005). Beyond green capitalism: Providing an alternative discourse for the environmental movement and natural resource management. Middle States Geographer 38: 69-76. Retrieved March 6, 2011 from: http://geographyplanning.buffalostate.edu/MSG2005/10\%20Barron.pdf

Blank, S.C. (1998). The end of agriculture in the American portfolio. Westport, CT: Quorum.

Bocock, R. (1993). Consumption. New York: Routledge.

Browne, W., J. Skees, L. Swanson, P. Thompson, \& L. Unnevehr. (1992). Sacred cows and hot potatoes. Boulder, CO: Westview.

Busch, L. (2000). The moral economy of grades and standards. Journal of Rural Studies 16(3), 273-283.

Cameron, J., \& J.K. Gibson-Graham. (2003). Feminising the economy: Metaphors, strategies, politics. Gender, Place and Culture 10(2), 145-158.

Carlsson, C., \& F. Manning. (2010). Nowtopia: Strategic exodus? Antipode 42(4): 924-954.

Diamond, A., \& R. De Soto. (2009). Facts on direct-to-consumer food marketing: Incorporating data from the 2007 Census of Agriculture. Agricultural Marketing Service: U.S. Department of Agriculture. Retrieved June 9, 2010 from: http://www.ams.usda.gov/AMSv1.0/getfile?dDocName=STELPRDC5076729

Dunn, K. (2005). Interviewing. In Hay, I. (Ed.), Qualitative research methods in human geography (2nd ed.) (pp. 79-105). Melbourne: Oxford University Press.

Fisher, S.L. (Ed.) (1993). Fighting back in Appalachia: Traditions of resistance and change. 
Philadelphia: Temple University Press.

Gibson-Graham, J.K. (2006a). The end of capitalism (as we knew it): A feminist critique of political economy (2nd ed.). Oxford: Blackwell.

Gibson-Graham, J.K. (2006b). A postcapitalist politics. Minneapolis, MN: University of Minnesota Press.

Guthman, J. (2004). Agrarian dreams: The paradox of organic farming in California. Berkeley, CA: University of California Press.

Halweil, B. (2002). Home grown: The case for local food in a global market. Washington, DC: Worldwatch Institute.

Hay, I. (Ed.). (2005). Qualitative research methods in human geography (2nd ed.). Melbourne: Oxford University Press.

Hightower, J. (1975). Eat your heart out: Food profiteering in America. New York: Crown.

Hubbard, K. (2009). Out of hand: Farmers face the consequences of a consolidated seed industry. Farmer to Farmer Campaign on Genetic Engineering, National Family Farm Coalition. Retrieved June 9, 2010 from: http://farmertofarmercampaign.com/Out\%20of\%20Hand.FullReport.pdf

Jacob, J.C. 1996. The North American back-to-the-land movement. Community Development Journal 31(3), pp. 241-249.

Kingsolver, B. (2007). Animal, vegetable, miracle: A year of food life. New York: HarperCollins.

Lewis, R.L. (1998). Transforming the Appalachian countryside: Railroads, deforestation, and social change in West Virginia, 1880-1920. Chapel Hill, NC: University of North Carolina Press.

Leyshon, A., R. Lee, \& C. Williams (Eds.). (2003). Alternative economic spaces. London: 
Sage.

Marx, K. (1973). Grundrisse. (Nicolaus, M., Trans.) New York: Vintage.

Miller, K.K., \& T.G. Johnson. (2009). The role of agriculture and farm household diversification in the rural economy of the United States. Organisation for Economic Cooperation and Development Trade and Agriculture Directorate. Paris: OECD. Retrieved March 24, 2010, from: http://www.oecd.org/dataoecd/35/46/43245626.pdf

Nabhan, G. (Ed.). (2008). Renewing America's food traditions: Saving and savoring the continent's most endangered foods. White River Junction, VT: Chelsea Green.

Nelson, M.K., \& J. Smith. (1999). Working hard and making do: Surviving in small town America. Berkeley, CA: University of California Press.

Oberhauser, A. (2005). Scaling gender and diverse economies: Perspectives from Appalachia and South Africa. Antipode 37(5), 863-874.

O’Brien, J. (2001). At home in the heart of Appalachia. New York: Knopf.

Ollman, B. (1971). Alienation: Marx's conception of man in capitalist society. New York: Cambridge University Press.

OTA. (2010). Industry statistics and projected growth. Organic Trade Association. Retrieved June 9, 2010 from: http://www.ota.com/organic/mt/business.html

Patel, R. (2007). Stuffed and starved: The hidden battle for the world food system. Brooklyn: Melville House.

Petrini, C. (2003). Slow food: The case for taste. New York: Columbia University Press.

Pollan, M. (2006). The omnivore's dilemma: A natural history of four meals. New York: Penguin.

Salstrom, P. (2005). Newer Appalachia as one of America’s last frontiers. In Pudup, M. B., 
Billings, D. B., \& Waller, A. L. (Eds.), Appalachia in the making: The mountain South in the nineteenth century (pp. 76-102). Chapel Hill, NC: University of North Carolina Press. Schlosser, E. (2001). Fast food nation: The dark side of the all-American meal. Boston: Houghton Mifflin.

Shackelford, L. \& B. Weinberg (Eds.). (1977). Our Appalachia: An oral history. New York: Hill \& Wang.

Shiva, V. (2000). Stolen harvest: The hijacking of the global food supply. Cambridge, MA: South End.

Slocum, R. (2006). Whiteness, space and alternative food practice. Geoforum 38(3), 520-533.

Smith, R. (2001, June 4). Five largest grocery retailers control 41\% of food sales. Feedstuffs. Retrieved June 9, 2010 from: http://www.accessmylibrary.com/article-1G175453747/five-largest-grocery-retailers.html

Solnit, R. (2010, December 22). Iceberg economies and shadow selves. The Nation. Retrieved March 6, 2011 from: http://www.thenation.com/article/157310/iceberg-economies-andshadow-selves

Tulip, K. \& L. Micheals. (2004). A rough guide to the UK farming crisis. Oxford: Corporate Watch.

U.S. Census Bureau. (2010). West Virginia QuickFacts. Retrieved December 15, 2010 from: http:/quickfacts.census.gov/qfd/states/54000.html

USDA. (2007). Agricultural census table 44. Retrieved June 9, 2010 from: http://www.agcensus.usda.gov/Publications/2007/Full_Report/Volume_1,_Chapter_2_U S_State_Level/st99_2_044_044.pdf

USDA. (2009). Farmers market growth: 1994-2009. USDA-AMS Marketing Services Division. 
Retrieved June 9, 2010 from:

http://www.ams.usda.gov/AMSv1.0/ams.fetchTemplateData.do?template=TemplateS\&na vID=WholesaleandFarmersMarkets\&leftNav=WholesaleandFarmersMarkets\&page=WF MFarmersMarketGrowth\&description=Farmers\%20Market\%20Growth\&acct=frmrdirmk $\mathrm{t}$

Winchester, H. (2005). Qualitative research and its place in human geography. In Hay, I. (Ed.), Qualitative research methods in human geography (2nd ed.) (pp. 3-18). Melbourne: Oxford University Press. 


\section{Tables}

Table 1

Vegetables Grown in Participant Households

\begin{tabular}{|c|c|c|}
\hline $\begin{array}{l}\text { Vegetable grown in } \\
\text { participant household } \\
\text { (38 vegetables total) }\end{array}$ & $\begin{array}{l}\text { Number of participant households growing } \\
\text { this vegetable } \\
\text { (out of } 23 \text { households total) }\end{array}$ & $\begin{array}{l}\text { Percentage of participant households } \\
\text { growing this vegetable } \\
\text { (out of } 23 \text { households total) }\end{array}$ \\
\hline Asparagus & 5 & $22 \%$ \\
\hline Beans, shell & 2 & $9 \%$ \\
\hline Beans, snap & 18 & $78 \%$ \\
\hline Beets & 7 & $30 \%$ \\
\hline Broccoli & 10 & $43 \%$ \\
\hline Brussels Sprouts & 5 & $22 \%$ \\
\hline Cabbage & 10 & $43 \%$ \\
\hline Carrots & 7 & $30 \%$ \\
\hline Cauliflower & 4 & $17 \%$ \\
\hline Celery & 1 & $4 \%$ \\
\hline Corn, sweet & 19 & $83 \%$ \\
\hline Cucumbers & 9 & $39 \%$ \\
\hline Edamame & 1 & $4 \%$ \\
\hline Eggplant & 3 & $13 \%$ \\
\hline Garlic & 10 & $43 \%$ \\
\hline Greens & 4 & $17 \%$ \\
\hline Kale & 8 & $35 \%$ \\
\hline Kohlrabi & 2 & $9 \%$ \\
\hline Leeks & 1 & $4 \%$ \\
\hline Lettuce & 14 & $61 \%$ \\
\hline Melons & 8 & $35 \%$ \\
\hline Okra & 1 & $4 \%$ \\
\hline Onions & 18 & $78 \%$ \\
\hline Parsnips & 2 & $9 \%$ \\
\hline Peas & 11 & $48 \%$ \\
\hline Peppers, sweet & 17 & $74 \%$ \\
\hline Peppers, hot & 18 & $78 \%$ \\
\hline Potatoes & 20 & $87 \%$ \\
\hline Radishes & 2 & $9 \%$ \\
\hline Rutebagas & 1 & $4 \%$ \\
\hline Salsify & 1 & $4 \%$ \\
\hline Spinach & 6 & $26 \%$ \\
\hline Squash, summer & 17 & $74 \%$ \\
\hline Squash, winter & 16 & $70 \%$ \\
\hline Sweet potatoes & 5 & $22 \%$ \\
\hline Swiss chard & 10 & $43 \%$ \\
\hline Tomatoes & 23 & $100 \%$ \\
\hline Turnips & 3 & $13 \%$ \\
\hline
\end{tabular}


Table 2

Fruits and Nuts Grown in Participant Households

Fruit or nut grown in participant household (18 fruits and nuts total)

Apples

Blackberries

Blueberries

Cherries

Currants

Filberts

Gooseberries

Grapes

Hickory nuts

Paw Paws

Peaches

Pears

Plums

Quince

Raspberries

Rhubarb

Strawberries

Walnuts
Number of participant households growing this fruit or nut (out of 23 households total) 18

7

13

5

3

1

1

3

2

2

10

9

1

4

1

5

8

1
Percentage of participant households growing this fruit or nut (out of 23 households total) $78 \%$

$30 \%$

$57 \%$

$22 \%$

$13 \%$

$4 \%$

$4 \%$

$13 \%$

$9 \%$

$9 \%$

$43 \%$

$39 \%$

$4 \%$

$17 \%$

$4 \%$

$48 \%$

$22 \%$

$35 \%$ 
Table 3

Field Crops Grown in Participant Households

Field crops grown in participant household (4 field crops total)

Corn

Hay

Oats

Sorghum
Number of participant households growing this field crop (out of 23 households total) 5

7

1

2
Percentage of participant households growing this field crop

(out of 23 households total) $22 \%$

$30 \%$

$4 \%$

$9 \%$ 
Table 4

Herbs Grown in Participant Households

Herb grown in participant household

(27+ herbs total)

Basil

Calendula

Catnip

Chives

Cilantro

Comfrey

Dill

Echinacea

Fennel

Ginseng

Hops

Horseradish

Lavender

Lemon Balm

Marjoram

Medicinal herbs, other

Mint

Oregano

Parsley

Rosemary

Sage

Savory

St. John's Wort

Stevia

Tarragon

Thyme

Tobacco
Number of participant households growing this herb

(out of 23 households total)

16

4

3

8

4

4

4

5

6

2

2

2

1

1

5

7

7

2

7

5

12

12

8

9

1

3

1

1

9

1
Percentage of participant households growing this herb

(out of 23 households total)

$70 \%$

$17 \%$

$13 \%$

$35 \%$

$17 \%$

$17 \%$

$22 \%$

$26 \%$

$9 \%$

$9 \%$

$4 \%$

$4 \%$

$22 \%$

$30 \%$

$9 \%$

$30 \%$

$22 \%$

$52 \%$

$52 \%$

$35 \%$

$39 \%$

$4 \%$

$14 \%$

$4 \%$

$4 \%$

$39 \%$

$4 \%$ 


\section{Table 5}

Livestock Raised in Participant Households

Livestock raised in participant household Number of participant households (14 types of livestock total)

Bass

Catfish

Cattle, beef

Cattle, dairy

Chickens, layers

Ducks

Geese

Goats

Honeybees

Pigs

Rabbits

Sheep

Trout

Turkeys

\section{raising this livestock}

(out of 23 households total) 3

2

6

2

9

1

1

1

2

6

5

1

1

1

1
Percentage of participant households raising this livestock

(out of 23 households total)

$13 \%$

$9 \%$

$26 \%$

$9 \%$

$39 \%$

$4 \%$

$4 \%$

$9 \%$

$26 \%$

$22 \%$

$4 \%$

$4 \%$

$4 \%$

$4 \%$ 
Table 6

Hunting and Fishing in Participant Households

Wild game hunted or fished in participant household (13

types of game and fish total)

Bass

Bluegill

Catfish

Deer

Grouse

Fish, total

Perch

Pike

Quail

Rabbits

Squirrel

Trout

Turkey

Walleye
Number of participant households hunting or fishing this wild game (out of 23 households total) 5 5

4

12

2

12

2

1

1

1

3

4

3

1

2
Percentage of participant households hunting or fishing this wild game (out of 23 households total)

$22 \%$

$22 \%$

$17 \%$

$52 \%$

9\%

$52 \%$

$9 \%$

$4 \%$

$4 \%$

$13 \%$

$17 \%$

$13 \%$

$4 \%$

$9 \%$ 
Table 7

Foraging in Participant Households

Item foraged in participant household

(17+ items total)

Blackberries

Elderberries

Filberts

Fruits, total

Ginseng

Greens

Ground cherries

Hickory nuts

Maple sap

Medicinal herbs, other

Mushrooms, total

Nuts, total

Paw Paws

Persimmons

Plums

Quinces

Ramps

Raspberries

Walnuts
Number of participant households foraging this item (out of 23 households total) 9

4

1

12

1

1

1

2

2

3

9

4

1

1

1

1

2

6

2
Percentage of participant households foraging this item (out of 23 households total) $39 \%$

$17 \%$

$4 \%$

$52 \%$

$4 \%$

$4 \%$

$4 \%$

$9 \%$

$9 \%$

$13 \%$

$39 \%$

$17 \%$

$4 \%$

$4 \%$

$4 \%$

$4 \%$

$9 \%$

$26 \%$

$9 \%$ 


\section{Appendix A}

\section{Household Economic Survey}

Section I. Food Production Activities

1. What food production activities are you involved in?
a. Vegetable gardening
f. Wild foraging of plants/fungi
b. Fruit/nut cultivation
g. Hunting wild game
c. Herb cultivation (culinary)
h. Fishing
d. Herb cultivation (medicinal)
i. Other (explain)

e. Livestock rearing

1. Please list the vegetables that you cultivate.

2. Please list the fruits, berries, and/or nuts that you cultivate.

3. Please list the culinary and/or medicinal herbs that you cultivate.

4. From which of the following sources do you get seeds/plants/garden supplies/etc.?
a. Large chain stores
f. Friends or family
b. Local home \& garden stores
g. I save and start my own seeds
c. Local nurseries/greenhouses
h. $\overline{\text { Other }}$ (specify)
d. Mail-order catalogs
e. Internet sites

5. Please list types and quantities of livestock that you raise.

6. Do you grow your own livestock fodder? Please specify varieties.

7. Do you buy additional feed for your livestock? If yes, from what sources?

8. Do you forage plants and/or fungi in the wild? If yes, please specify varieties.

9. Do you hunt and/or fish? If yes, please specify varieties.

10. In approximate square feet, what is the total size of your food garden(s)?

11. How much food do you produce annually?

i. Enough to eat fresh in season. 
j. Enough to eat fresh and preserve for later.

k. Enough to eat fresh, preserve, and share with family/friends/neighbors.

l. Enough to eat, preserve, share, and sell.

12. Approximately how much money do you spend each year on activities related to food production?

13. Do you gain any cash income from sale of home-grown food products (i.e., fresh fruits/vegetables, canned goods, meat, eggs, herbal products, etc.)?

14. If yes, approximately how much money do you receive each year from sale of these products? does this figure represent?

15. Approximately how much time do you spend each week on activities related to food production?

16. How long have you been producing food?
a. $1-5$ years
b. $5-10$ years
c. 10-20 years
d. More than 20 years

17. How have your food production activities changed over time?
a. My food production activities have increased/diversified over time.
b. My food production activities have decreased over time.
c. My food production activities have stayed about the same.

18. Please explain the main reasons why your food production activities have changed over time, if applicable (e.g., more/less time available; financial opportunities/constraints; health concerns, etc):

Section II. Household Demographics

19. How many people live in your household? (include self)

20. What are their ages? (include self)

21. What is your marital status?
a. Single, never married
b. Married, living with spouse
c. Cohabitating with partner
d. Separated/divorced

e. Widowed

f. Other (explain)

22. What is the highest level of education that you have completed?
a. None
b. Elementary school
c. Junior high school
d. Senior high school
e. GED
f. Technical/trade school

g. Some college/university

h. Bachelor's degree (B.A.)

i. Master's degree (M.A.)

j. Doctorate (Ph.D) 
23. What is your residential status?
a. I own my home without a mortgage or loan.
b. I own my home with a mortgage or loan.
c. I rent my home.
d. I live in my home without payment or rent.

24. Your home is located on how many acres of land?

25. How long have you lived at your current residence?

26. Where would you say you are from?

27. What are the sources of income in your household?

b. Wages

c. Entrepreneurial activities

d. Goods/services produced at home

e. Child support

f. Unemployment insurance

g. Public assistance h. Pension/Social Security

i. Rent

j. Job training fund

k. Gifts

l. Other (explain)

28. What is your annual household income?

$\$ 0-\$ 4,999$

$\$ 5,000-\$ 9,999$

\$10,000-\$14,999

\$15,000-\$19,999

$\$ 20,000-\$ 24,999$

$\$ 25,000-\$ 29,999$

$\$ 30,000-\$ 34,999$

$\$ 35,000-\$ 39,999$

$\$ 40,000-\$ 49,000$

$\$ 50,000-\$ 59,000$

$\$ 60,000-\$ 69,000$

$\$ 70,000-\$ 79,000$

$\$ 80,000-\$ 89,000$

$\$ 90,000-\$ 100,000$

Above \$100,000

29. What are the occupations of those people earning an income in your household?

30. Do they work full- or part-time? 


\section{Appendix B}

Interview Guide

1. How did you become interested in producing your own food?

a. How did you learn these skills?

b. What are your main motivations for producing your own food?

2. Is food production a financial decision for you?

a. Would your food production activities change if your financial situation changed for the better?

b. Would your food production activities change if your financial situation changed for the worse?

c. What would you do if you could no longer produce your own food?

3. How much of your overall diet comes from the food you produce?

a. How do your food production activities change seasonally?

b. How do these activities affect your household food budget?

4. What foods do you usually purchase rather than produce yourself?

a. Why do you purchase these foods rather than producing them yourself?

b. From what sources do you purchase these foods?

c. Why do you purchase foods from these particular sources?

5. How would you describe the main benefits of producing your own food?

6. How would you describe the main drawbacks of producing your own food?

7. Do ethics play a role in your food production activities?

a. Do your food production activities express or reflect your personal ethics or moral values?

b. Are those values expressed or not expressed in other food systems?

8. Do you see yourself as part of a food movement?

a. How do you think other people view your food production activities?

b. What are the main reasons you think other people may have for producing food?

9. Do you consider yourself a food producer or a food consumer?

10. How has your relationship to food changed because of your food production activities?

a. How do you think other people's relationships to food have changed over time?

b. How do you think food production will change in the future?

c. Do you think people will become more or less interested in producing their own food in the future?

d. Would you recommend that other people engage in the kinds of food production activities that you undertake? 


\section{Appendix C}

Institutional Requirements

IRB Protocol Approval:

Tracking \#: H-22578

PI: Wilson, Bradley

Title: Subsistence and Resistance: The Politics of Food Production for Household Consumption in North-Central West Virginia

Version: 4

Status: Exempt

Status Date: 8/17/2011 10:19:13 AM

Board: Board Gold

Approval Date: 8/17/2010 